\title{
Action Recognition and Suspicious Action Detection with Mixture Distributions of Action Primitives
}

\author{
Yoshio Iwai Non-member (Osaka University, iwai@sys.es.osaka-u.ac.jp) \\ Yasuhiro Aoki Non-member (Osaka University, aoki@yachi-lab.sys.es.osaka-u.ac.jp) \\ Hiroshi Ishiguro Non-member (Osaka University, ishiguro@sys.es.osaka-u.ac.jp)
}

Keywords: suspicious action detection, action primitives, mixture distributions, sequential Monte Carlo

In recent years, the social environment has become more complex and people's personal lives have become more varied, so the development of security systems that detect hazards and allow us to avoid these has become necessary for us to be safe and secure. However, it is too heavy work for administrators to monitor the environment in 24 hours because they are tied on monitor TVs, and such heavy work causes a mistake. Therefore, a system would need facilities to detect unusual situations automatically and inform system administrators of unusual situations by sensing and recognizing our environment. Such a system would reduce surveillance load, because administrators only pay attention when the system warns.

To detect suspicious actions, the system needs to detect and track people surreptitiously. Cameras have usually been utilized as environmental sensors because they do not make us feel uncomfortable. People are detected and tracked through input images by image processing, and our purpose is to do this and to recognize their actions by using trajectories of movement.

One approach using Monte Carlo method has been proposed to detect suspicious actions. However, there is a problem that they assume that the distribution of human action state would be uniform. In this paper, we reformulate human actions by the posterior probability and approximate it by the Monte Calro method. By this reformulation, we can treat human actions within the Monte Calro approximation theory, and also solve the local minimum problem of sequential Monte Calro method.

The action recognition is performed by MAP estimation using the posterior probability, $p\left(M_{t} \mid z_{t-k: t}\right)$, of action model $M_{t}$ at time $t$ given the observation sequence $z_{t-k: t}$, where $k$ is a number of observation frames. Figure 1 shows the probability structure of the proposed framework.

We consider an action not in the action database as a suspicious action. However, all sample points are generated from the action database and no sample points are generated from a suspicious actions. Therefore, we need some criteria to detect suspicious actions. In this research we use the probability $p\left(z_{t} \mid x_{t}\right)$ that means the accuracy of the prediction of

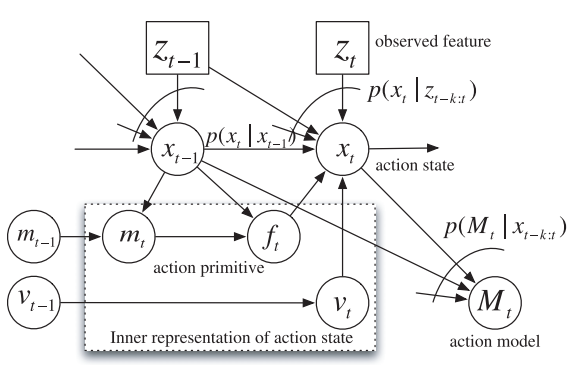

Fig. 1. Probability structure of the proposed framework

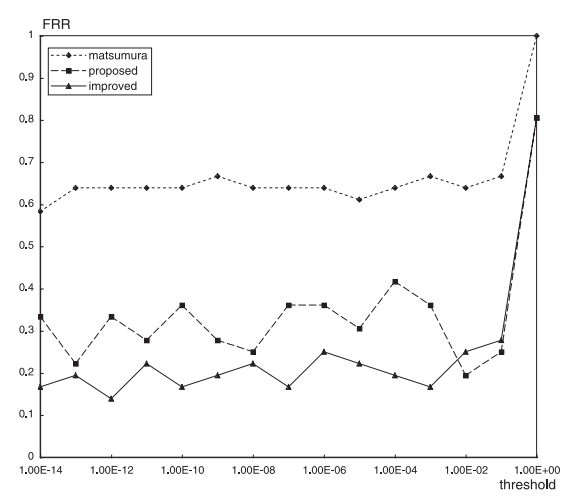

Fig. 2. Suspicious action detection rate varying the threshold value

actions in the action database, and we determined an action as a suspicious action when all likelihood $p\left(z_{t} \mid x_{t}^{(i)}\right)$ of all samples $x_{t}^{(i)}$ becomes less than a certain threshold value. Figure 2 shows the experimental results of the proposed framework.

In conclusion, we have proposed a generic framework for detecting suspicious actions with mixture distributions of action primitives, of which collection represents human actions. We used an Bayesian approach to recognize human actions and approximate the probability by the Monte Carlo method. In future work, we will investigate the effects of these parameters and improve the recognition rate. 


\title{
行動素の混合分布に基づく行動認識と例外行動の検出
}

\author{
非会員 岩井 儀雄* 非会員 青木 康洋* \\ 非会員 石黒＼cjkstart浩*
}

\section{Action Recognition and Suspicious Action Detection with Mixture Distributions of Action Primitives}

Yoshio Iwai*, Non-member, Yasuhiro Aoki*, Non-member, Hiroshi Ishiguro*, Non-member

In this paper, we propose a generic framework for detecting suspicious actions with mixture distributions of action primitives, of which collection represents human actions. The framework is based on Bayesian approach and the calculation is performed by Sequential Monte Carlo method, also known as Particle filter. Sequential Monte Carlo is used to approximate the distributions for fast calculation, but it tends to converge one local minimum. We solve that problem by using mixture distributions of action primitives. By this approach, the system can recognize people's actions as whether suspicious actions or not.

キーワード: 例外行動検出, 行動素, 混合分布, 逐次モンテカルロ法

Keywords: suspicious action detection, action primitives, mixture distributions, sequential Monte Carlo

\section{1. はじめに}

近年, 社会がますます複雑化し，様々な機器やシステム が導入され続けている。そのため, 機器やシステムの安全 を達成するとともに，人に関わる様々な空間の安全と安心 を確保する必要性が増大してきている。その際に，機械や システムは確実に，しかしさりげなく我々の活動を守り，支 援することが要求されている(1)。このようなシステムを実 現するためには，環境内で生じる様々な事象をシステムが 自動的に把握する必要がある。そのための情報入力手段と して，従来から様々なセンサが利用されてきた。特に，画 像センサについては得られた画像の処理方法により様々な 事象に対応できる上，また，監視カメラ用途として撮影す ることによる心理的抑止効果や, 記録映像の章構成などの 利点を有するため, 従来から多数の研究が行われてきた。

一般に，画像による行動認識システムは，人物追跡と行 動認識の 2 つのモジュールから構成されている。人物追跡 に関しては, ブースティング手法を利用した人物検出 ${ }^{(2)} や$, ベイズアプローチに基づく方法 (3) などが提案されている。 人物追跡手法は様々なものが提案されている ${ }^{(4)}$ が, 追跡と 認識の 2 つモジュールはそれぞれ独立に設計できるため, どのような追跡方法を選んでも良い。本研究では，特に人 物行動認識と例外の検出に焦点を当てる。

\footnotetext{
* 大阪大学大学院基礎工学研究科

干 560-8531 大阪府豊中市待兼山町 1-3

Graduate School of Engineering Science, Osaka University

1-3, Machikaneyama, Toyonaka, Osaka 560-8531
}

例外検出のアプローチとして, Nanri らの立体高次局所 自己相関特徴を用いた手法 ${ }^{(5)} や$, Boiman らのデータベー ス内の画像から作成したパッチの組み合わせによってクエ リ画像を表現する手法 ${ }^{(6)}$ がある。これらの手法は, クエリ 画像が学習画像群と時間的 ·空間的にどの程度類似するか を計算して，目立った変化が表れたときに例外検出とする アプローチである。しかしながら，あくまでも変化点を検 出するものであり, どのような行動を行っていたかを認識 するものではない。

行動認識には, 確率モデルを利用する方法がよく用いら れている。そのなかでも, 隠れマルコフモデル (HMM) (7) が行動認識によく用いられている。例えば, Oliver らによ る二人の人物の相互干涉をモデル化したもの ${ }^{(8)}$ や青木らの 日常の行動を学習して例外検出へ応用したもの (9) などが ある。一方, 逐次モンテカルロ法を行動認識に応用した手 法 ${ }^{(10) \sim(12)}$ も提案されている。この手法は, 逐次モンテカ ルロ法による追跡で用いる内部状態に, 現在実行中の行動 を示すラベルを付与して内部状態を拡散し, 元の追跡用の 内部状態で周辺化積分することで, 行動の事後確率を計算 する。

逐次モンテカルロ法は, 隠れマルコフモデルに比ベサン プル数を押さえることにより高速に計算することが出来る うえ, 時系列データのノイズに対しても, ロバストに認識 できるなどの利点があるが, 逐次モンテカルロ法の性質上, 多峰性を持つ分布はうまく取り扱うことができない。しか し, Vermaakら (13) によってこのような多峰性問題の解決 策が提案されている。その方法は, 分布が多峰性を持つの 
であればもとの分布を局所分布の和によって表すことで解 決するものであり，Vermaak らはこれによって，複数の人 物を同時に追跡することに成功している。本研究ではこの 方法を応用することで，行動モデルの認識における多峰性 問題を回避する。また，行動モデルの学習の際，全ての可 能な例外を列挙することは不可能であるため例外行動その ものを学習することは非常に困難である。そこで本研究で は，頻繁に観測されるような行動を通常の行動とみなして 子女学習し行動モデルのデータベースを構築するものとし, データベースに無い行動が観測されたときを例外行動発生 として扱う。

\section{2. 行動モデル}

〈2·1〉 行動モデルの表現人物の行動は, 図 1 に示す ような, 様々なセンサから得られる観測空間上の軌跡とし て考えることができる。また，ある一連の行動には部分的 によく似た行動が存在する。これらは特徵空間上では，部 分的に重なる軌跡として表現される。そこで，本研究では 特徵空間の行動軌跡同士で重なる部分を共有するように軌 跡を分割し，分割された部分的な軌跡を行動素と呼ぶ。そ して, 人物の行動モデルを, 行動素の遷移列として表現す る。行動モデルの様子を図 2 に示す。ここで各 $m$ は行動素 であり，特徵空間上に軌跡 $z=m(f)$ を描く。ただし， $z$ は 特徵空間上での観測特徵量であり $f$ は軌跡 $m$ のパラメー 夕である。例えば, 特徴空間として, 人物の関節角度を選 んだ場合は $z$ は人体の各関節角度を表すべクトルであり, $m(f)$ は関節角度の変化軌跡を表している。 $f$ を増加させ 軌跡を描くことで行動素が再生されるので，本研究ではパ ラメータ $f$ のとをフレームと呼ぶ。

$\langle 2 \cdot 2\rangle$ 行動の内部状態人物の行動にはマルコフ性 を持つ内部状態 $x$ があり, 現時刻 $t$ の内部状態 $x_{t}$ に従って

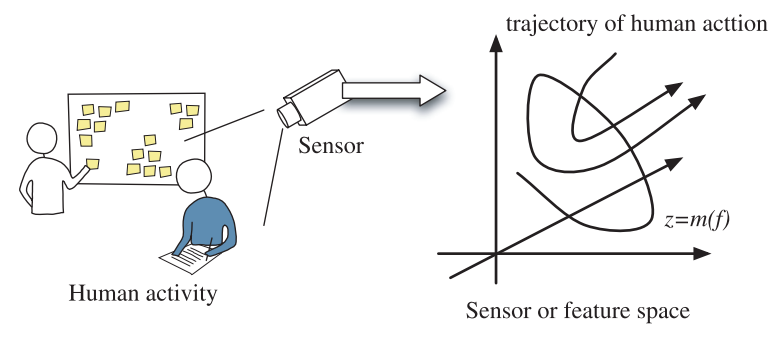

Fig. 1. Trajectories represent human activities

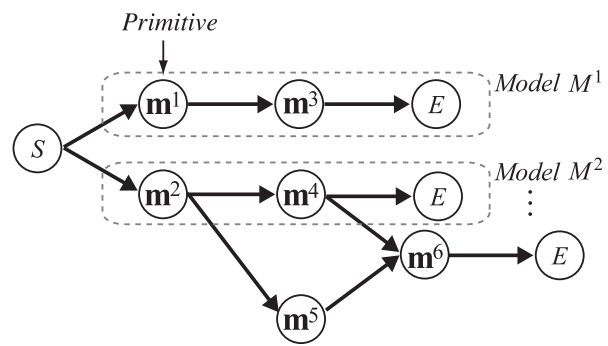

Fig. 2. Action model
特徵量 $z_{t}$ が観測されるとする。すなわち, 次式のような遷 移モデルを考える。

$$
\begin{aligned}
& x_{t} \sim p\left(x_{t} \mid x_{t-1}\right) \\
& z_{t} \sim p\left(z_{t} \mid x_{t}\right) \cdots
\end{aligned}
$$

本研究の場合, 状態 $x$ は行動モデルの内部状態であるので, 行動素間の遷移と行動素軌跡の再生を状態 $x$ が表現できれ ばよい。

行動素の遷移を表すためには, 内部状態 $x$ が再生中の行 動素 $m$ を含んでいれば良い。状態 $x_{t}$ として $x_{t}=\left(m_{t}, y_{t}\right)$ という形を考えると, 状態遷移確率はべイズルールより

$$
p\left(x_{t} \mid x_{t-1}\right)=p\left(y_{t} \mid m_{t}, x_{t-1}\right) p\left(m_{t} \mid x_{t-1}\right) \cdots \cdots
$$

である。これは, 過去の状態から現在の行動素 $m_{t}$ へ の遷移が $p\left(m_{t} \mid x_{t-1}\right)$ で与えられ, 行動素 $m_{t}$ の再生が $p\left(y_{t} \mid m_{t}, x_{t-1}\right)$ で与えられることを示している。

次に，ある行動素 $m$ の再生について考える。現在の行動 素軌跡のフレーム位置 $f_{t}$ とフレームの再生速度 $v_{t}$ を用い ると, 状態方程式

$$
\begin{aligned}
f_{t} & =f_{t-1}+v_{t-1}+\mathcal{N}_{f} \\
v_{t} & =v_{t-1}+\mathcal{N}_{v} \cdots \cdots \\
z_{t} & =m\left(f_{t}\right) \cdots \cdots \cdots
\end{aligned}
$$

によって, 行動素軌跡 $z=m(f)$ を再生できる。ただし, $\mathcal{N}_{f}, \mathcal{N}_{v}$ はそれぞれフレーム位置 $f$ と速度 $v$ のノイズであ る。これより, ある行動素軌跡 $m$ の状態 $(f, v)$ の遷移確 率は

$$
p\left(f_{t}, v_{t} \mid f_{t-1}, v_{t-1}\right)=p\left(v_{t} \mid v_{t-1}\right) p\left(f_{t} \mid f_{t-1}, v_{t-1}\right)
$$

となる。

以上より, 行動素の再生状態を $y_{t}=\left(f_{t}, v_{t}\right)$ とすれば, 内部状態 $x_{t}$ は $x_{t}=\left(m_{t}, f_{t}, v_{t}\right)$ であり, その遷移確率は

$$
p\left(x_{t} \mid x_{t-1}\right)=p\left(v_{t} \mid v_{t-1}\right) p\left(f_{t} \mid m_{t}, x_{t-1}\right) p\left(m_{t} \mid x_{t-1}\right)
$$

とできる。

〈2・3〉 内部状態の尤度 観測值による状態の尤度 $p\left(z_{t} \mid x_{t}\right)$ については, 観測值 $z_{t}$ と, 状態 $x_{t}$ が示す特徽量 $m_{t}\left(f_{t}\right)$ との距離を利用する。まず, 距離 $d\left(z_{t}, x_{t}\right)$ を次式で 計算する。

$$
d\left(z_{t}, x_{t}\right)=\left(z_{t}-m_{t}\left(f_{t}\right)\right)^{T} \Sigma^{-1}\left(z_{t}-m_{t}\left(f_{t}\right)\right) \cdots
$$

ここで， $\Sigma$ は共分散行列を表す。なお，行動素 $m_{t}$ は，学習 データとして与えられる観測データ $z$ から, 作成されるの で, これらの次元は通常一致している。尤度分布 $p\left(z_{t} \mid x_{t}\right)$ は距離 $d(\cdot)$ を用いて,

$$
p\left(z_{t} \mid x_{t}\right) \propto \exp \left(-d\left(z_{t}, x_{t}\right)\right)
$$

とする。 


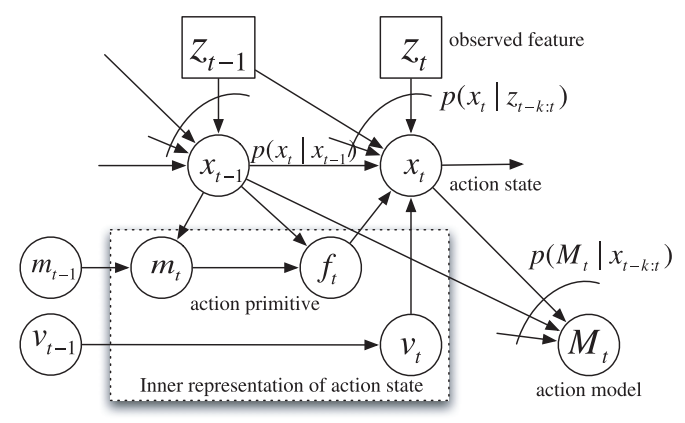

Fig. 3. Probability structure of the proposed framework

\section{3. 行動認識と例外検出}

〈3・1〉 行動の認識 行動モデルの認識は, 時刻 $t-k$ から現在時刻 $t$ までの観測系列 $z_{t-k: t}$ が得られたときの, 時刻 $t$ での行動モデル $M_{t}$ の事後確率 $p\left(M_{t} \mid z_{t-k: t}\right)$ の分布 を求めることで行う。図 3 に, 提案するフレームワークの 確率構造を示す。事後確率は内部状態 $x$ を用いることで次 のように計算できる。

$$
\begin{aligned}
& p\left(M_{t} \mid z_{t-k: t}\right) \\
& \quad=\int p\left(M_{t} \mid x_{t-k: t}\right) p\left(x_{t-k: t} \mid z_{t-k: t}\right) d x_{t-k: t} \cdots
\end{aligned}
$$

ここで， $x_{t-k: t}$ は初期時刻 $t-k$ から現在時刻 $t$ までの内 部状態の系列である。また，各時刻での内部状態を，観測 系列のもとで条件付き独立とし, 状態 $x_{s}$ は, 未来の観測か ら影響を受けないとすると, 上式は,

$$
\begin{aligned}
p & \left(M_{t} \mid z_{t-k: t}\right) \\
& =\int p\left(M_{t} \mid x_{t-k: t}\right) \prod_{s=t-k}^{t} p\left(x_{s} \mid z_{t-k: s}\right) d x_{t-k: t}
\end{aligned}
$$

となる。この式は観測系列を用いて各時刻での内部状態を 推定することで，内部状態の遷移列を得て，その遷移列を 用いて行動モデルの事後確率を計算することを示している。

内部状態の推定 $p\left(x_{t} \mid z_{t-k: t}\right)$ は一時刻前の分布 $p\left(x_{t-1} \mid\right.$ $z_{t-k: t-1)}$ を用いて次のように逐次的に計算できる。

$$
\begin{array}{r}
p\left(x_{t} \mid z_{t-k: t-1}\right)=\int p\left(x_{t} \mid x_{t-1}\right) p\left(x_{t-1} \mid z_{t-k: t-1}\right) d x_{t-1} \\
\ldots \ldots \ldots \ldots \ldots \ldots \ldots \ldots \ldots \\
p\left(x_{t} \mid z_{t-k: t}\right)=\frac{1}{p\left(z_{t} \mid z_{t-k: t-1}\right)} p\left(z_{t} \mid x_{t}\right) p\left(x_{t} \mid z_{t-k: t-1}\right)
\end{array}
$$

ここで, $p\left(x_{t} \mid x_{t-1}\right)$ は状態の遷移確率を，また $p\left(z_{t} \mid x_{t}\right)$ は 尤度を表し，それぞれ $\langle 2 \cdot 2\rangle$ 節，〈2・3〉節で述べた通りである。 また, $p\left(z_{t} \mid z_{t-1}\right)$ は単なる正規化定数とみなせるため, その 分布の形状を知る必要は無い。計算機上での実装には, 状態 $x_{t}$ をサンプル $x_{t}^{(i)}$ で表し, 逐次モンテカルロ法による近似 計算を用いる。このサンプルは (13) 式中の分布 $p\left(x_{t} \mid x_{t-1}\right)$ によりサンプリングされる。

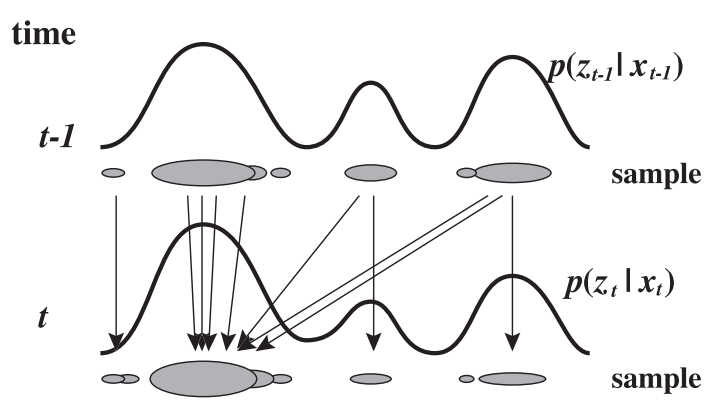

Fig. 4. Convergence to the local minimum

$\langle 3 \cdot 2\rangle$ 多峰性問題への対応状態 $x$ は遷移確率 $p\left(x_{t} \mid x_{t-1}\right)$ によってサンプリングされるため, 観測 $z_{t}$ を 考慮せず, 状態 $x_{t-1}$ のみによって更新される。このためサ ンプルの更新を繰り返すと, サンプル集合内の各サンプル の尤度 $p\left(z_{t} \mid x_{t}^{(i)}\right)$ が偏ってしまい近似精度が悪くなる。そ こで，現在のサンプル集合からリサンプリングすることで 新しくサンプル集合を作りなおし, 偏りを無くす必要があ る。リサンプリングは, 各サンプルに重み付けをし, 重み の大きいサンプルほど多く残すようにして行う。サンプル の重みとして, 観測值との尤度 $p\left(z_{t} \mid x_{t}^{(i)}\right)$ を用いる方法 ${ }^{(11)}$ が提案されているが, この場合, より尤度の高いサンプル にサンプル全体が集中してしまう。そのため多峰性を持つ 分布では, 図 4 に示すようにサンプルが局所分布に偏って しまい近似精度が悪くなる。偏りを無くすためのリサンプ リングが，かえって偏りを生む結果になってしまう。

このような多峰性問題は, 例えば, 複数の人物を同時に 追跡する場合などに表れる。この問題に対して Vermaak ら (13) は, 次のように状態の分布をいくつかの局所分布の 重み付き和の形で定義する手法を提案している。

$$
\begin{aligned}
& p\left(x_{t} \mid z_{t-k: t}\right) \stackrel{\text { def }}{=} \sum_{m=1}^{N_{m}} \pi_{m, t} p_{m}\left(x_{t} \mid z_{t-k: t}\right) \ldots \ldots . \\
& \sum_{m=1}^{N_{m}} \pi_{m, t}=1 \ldots \ldots \ldots \ldots \ldots \ldots \ldots \ldots \ldots \ldots
\end{aligned}
$$

ここで, $N_{m}$ は局所分布の数, $\pi_{m, t}$ は局所分布 $p_{m}$ に対す る時刻 $t$ での重みである。これを $(13),(14)$ 式に代入す ることによって, 次で示すように $p_{m}\left(x_{t-1} \mid z_{t-k: t-1}\right)$ から $p_{m}\left(x_{t} \mid z_{t-k: t}\right)$, および $\pi_{m, t-1}$ から $\pi_{m, t}$ への更新式を得る。

$$
\begin{aligned}
& p_{m}\left(x_{t} \mid z_{t-k: t-1}\right) \\
& \quad=\int p\left(x_{t} \mid x_{t-1}\right) p_{m}\left(x_{t-1} \mid z_{t-k: t-1}\right) d x_{t-1} \cdots \\
& p_{m}\left(x_{t} \mid z_{t-k: t}\right)=\frac{p\left(z_{t} \mid x_{t}\right) p_{m}\left(x_{t} \mid z_{t-k: t-1}\right)}{p_{m}\left(z_{t} \mid z_{t-k: t-1}\right)} \cdots \\
& \pi_{m, t}=\frac{\pi_{m, t-1} p_{m}\left(z_{t} \mid z_{t-k: t-1}\right)}{\sum_{n=1}^{N_{m}} \pi_{n, t-1} p_{n}\left(z_{t} \mid z_{t-k: t-1}\right)} \cdots \cdots
\end{aligned}
$$

上式を用いることにより, 多峰性を持つ分布を逐次モンテ カルロ法でうまく近似することができる。

本研究においても, 行動素が示す特徵空間上のある一点 
が，別の行動素の一点と近いことがあり，状態分布は多峰 性を持っている。そこで, 局所分布 $p_{m}$ を行動素別の状態 の分布とすることで，このような多峰性問題を回避するこ とができる。

〈3.3〉 逐次モンテカルロ法による近似計算 時刻 $t$ で のサンプル $x_{t}^{(i)}$ の重みを $w_{t}^{(i)}$ とすると，(15) 式は

$$
p\left(x_{t} \mid z_{t-k: t}\right)=\sum_{i=1}^{N} \pi_{m_{t}^{(i)}, t} w_{t}^{(i)} \delta_{x_{t}^{(i)}}\left(x_{t}\right) \cdots \cdots \cdots
$$

と近似できる。なお， $N$ はサンプルの総数であり, $m_{t}^{(i)}$ は サンプル $x_{t}^{(i)}$ が示す行動素である。また，ここでの $\delta_{a}(\cdot)$ は $a$ で值を持つディラックのデルタ関数である。

行動モデルの事後確率 $p\left(M_{t} \mid z_{t-k: t}\right)$ は，(12) 式をサンプ ルで近似して

$$
\begin{aligned}
& p\left(M_{t} \mid z_{t-k: t}\right) \\
& \quad=\sum_{i=1}^{N} p\left(M_{t} \mid x_{t-k: t}^{(i)}\right) \prod_{s=t-k}^{t} p\left(x_{s}^{(i)} \mid z_{t-k: s}\right) \cdots
\end{aligned}
$$

で計算できる。ここで, $x_{t-k: t}^{(i)}$ は $i$ 番目のサンプルが時刻 $t-k$ から時刻 $t$ までに辿ってきた状態の遷移列のことである。 一見すると，時刻 $t$ までに発生した全てのサンプルを記録し ておく必要があるように見えるが，事後確率 $p\left(M_{t} \mid x_{t-k: t}\right)$ は $\langle 4 \cdot 3\rangle$ 節で述べたように, 状態系列 $x_{t-k: t}$ が辿った行動 素遷移列 $m_{t-k: \tau}$ のみを必要とするため, $i$ 番目のサンプル が示す状態系列 $x_{t-k: t}^{(i)}$ はその行動素遷移列 $m_{t-k: \tau}^{(i)}$ のみを 記録しておけば良い。

サンプルの重み $w_{t}^{(i)}$ は,

$$
\begin{aligned}
\tilde{w}_{t}^{(i)} & =w_{t-1}^{(i)} p\left(z_{t} \mid x_{t}^{(i)}\right) \\
w_{t}^{(i)} & =\frac{\tilde{w}_{t}^{(i)}}{\sum_{j \in \mathcal{I}_{m}} \tilde{w}_{t}^{(j)}} \cdots
\end{aligned}
$$

で更新する。ここで, $\mathcal{I}_{m}$ はサンプル $x_{t}^{(i)}$ が示す行動素 $m_{t}^{(i)}$ と同じ行動素を示すサンプルの集合である。

〈3.4〉例外検出法 本研究では学習データベースに 存在しない行動はすべて例外行動として扱う。状態遷移 $p\left(x_{t} \mid x_{t-1}\right)$ による状態の更新は, 学習した行動モデルのデー タベースを用いて，次時刻での状態を予測していると考え られる。このとき, 尤度 $p\left(z_{t} \mid x_{t}\right)$ は予測の正しさを与えて おり，あるサンプルの尤度 $p\left(z_{t} \mid x_{t}^{(i)}\right)$ が小さいときは，その サンプルによる予測が外れていることを示している。もし， 全てのサンプルの尤度が十分に小さいときはデータベース に存在しない例外行動を観測した可能性がある。そこで, 本 研究では，あるサンプルの尤度 $p\left(z_{t} \mid x_{t}^{(i)}\right)$ があらかじめ指 定したしきい值 $\varepsilon_{L}$ を下回ったときに，そのサンプルの重 み $w_{t}^{(i)}$ を 0 とし, すべてのサンプルの重みが 0 となったと きに例外行動を検出したとする。なお，例外行動が検出さ れた場合はサンプル集合を再び初期化することで認識処理 を続けることができる。
〈3.5〉 サンプリングの問題と重みの改良サンプル は $p\left(x_{t} \mid x_{t-1}\right)$ によって更新されるとしたが, 行動モデルの データベース $D$ 内に

- $M_{1}: m_{1} \rightarrow m_{2} \rightarrow m_{3}$

- $M_{2}: \quad m_{4} \rightarrow m_{2} \rightarrow m_{5}$

のように共通の行動素を含むような行動モデルが存在する 場合や，次のような行動素のループを含む行動モデル

- $M_{3}: \quad m_{6} \rightarrow m_{7} \rightarrow m_{8} \rightarrow m_{7} \rightarrow m_{9}$

がある場合，一時刻前のみに基づいて更新すると問題が生 じることがある。例えば，最初の共通の行動素がある例の場 合, 現在の行動素を $m_{2}$ とすると, 遷移先は $m_{3}$ と $m_{5}$ が考 えられるため, 場合によってはあるサンプルの系列 $x_{t-k: t}^{(i)}$ が示す行動素遷移列が $m_{1} \rightarrow m_{2} \rightarrow m_{5}$ のようにデー タベースに無い遷移列を辿り得る。次のループを含む場合 の例でも同様に, サンプルの系列 $x_{t-k: t}^{(i)}$ が示す遷移列が $m_{6} \rightarrow m_{7} \rightarrow m_{9}$ のように, やはりデータベース内に存在 しない遷移列を辿り得る。

これは, 学習済みの行動素の遷移パターンから新しい行 動を類推できる, と言う意味では利点となり得る。しかし, 本研究のように, 有限のサンプルを用いて観測系列を行動 モデルデータベース $D$ と比較する場合では, データベー スに存在しない遷移列を辿ったサンプル $x_{t}^{(i)}$ は，その系列 $x_{t-k: t}^{(i)}$ による事後確率が

$$
\forall M \in D, \quad p\left(M \mid x_{t-k: t}^{(i)}\right)=0 .
$$

であるため, 行動モデルの認識には全く役に立たない。さ らに, 観測系列 $z_{t-k: t}$ がデータベースに学習済みの行動モ デルと同等の軌跡であった場合，先のデータベースに無い 遷移列を辿ったサンプルはいずれ尤度 $p\left(z_{t} \mid x_{t}^{(i)}\right)$ が小さな 值になり得る。しかし，行動素が遷移した直後は，それは 行動の分岐点にあたるため，尤度は低くならない。このた め，行動素が遷移した直後にリサンプリングを行った場合 で，かつデータベースに無い遷移を辿る方が尤度分布が高 くなってしまう場合や，そもそもサンプルの総数が少ない 場合などで，全てのサンプルがこのデータベースに無い遷 移列を辿るものに偏ってしまう恐れがある。しかしながら， 遷移してから暫く経つと予測が外れ出すため尤度が小さく なり，そのうちしきい值を下回り誤って例外として検出し てしまう。

この問題は，サンプルの数を増やせば解決できるが，場 合によっては大量のサンプルが必要となるため実用的には 困難である。そこで, 本研究ではサンプルの重みを計算す る際に，(22) 式を次式で置き換えることによってこの問題 を回避する。

$$
\tilde{w}_{t}^{(i)}=w_{t-1}^{(i)} p\left(z_{t} \mid x_{t}^{(i)}\right) T\left(x_{t-k: t}^{(i)}\right)
$$

ここで, $T\left(x_{t-k: t}^{(i)}\right)$ はサンプルの辿った行動素遷移列がデー タベース $D$ 内に存在するかどうかを示すブール值であり, 論理和 


$$
T\left(x_{t-k: t}^{(i)}\right)=\bigcup_{M \in D} F\left(M, m_{t-k: \tau}^{(i)}\right)
$$

で計算する。なお， $m_{t-k: \tau}^{(i)}$ は $i$ 番目のサンプルが辿った行 動素遷移列であり，F(.) は (31) 式のものと同一である。こ れは，データベース内に存在しない遷移列を辿ったサンプ ルの重みを強制的に 0 へと変更する操作である。重み 0 の サンプルはリサンプリングによって確実に他のサンプルに 置き換えられるため, データベースに無い遷移列を辿るサ ンプルは存在しなくなる。

このような処理を前節の処理（(22) 式）の代わりに行う ことにより，サンプル数が十分でない場合や，学習デー夕 ベース内にループがある場合においても，正しく例外行動を 検出することが出来る。具体的な精度は，実験の章で示す。

\section{4. 確率の設計}

〈4・1 $\rangle$ 行動素の遷移確率 ここでは行動素の遷移確 率 $p\left(m_{t} \mid x_{t-1}\right)$ について述べる。行動モデルのデータベー スには，ある行動素から別の行動素への遷移頻度が学習可 能であり，したがって遷移先を決定する分布 $p\left(m_{i} \mid m_{j}\right)$ は 既知のものとして扱える。しかし行動素の遷移は，ある行 動素を再生し終えてから起こるものであるため, 実際に遷 移が起こるかどうかはその時の行動状態 $x_{t-1}$ に依存する。 よって本研究では, 遷移確率 $p\left(m_{t} \mid x_{t-1}\right)$ を

$$
\begin{aligned}
p\left(m_{t} \mid x_{t-1}\right)= & r\left(x_{t-1}\right) p\left(m_{t} \mid m_{t-1}\right) \\
& +\left(1-r\left(x_{t-1}\right)\right) \delta\left(m_{t}, m_{t-1}\right) \cdots
\end{aligned}
$$

と定義する。ここで $r\left(x_{t-1}\right)$ は, 状態 $x_{t-1}$ が行動素の遷 移を起こすかどうかを表す確率である。また， $\delta\left(m_{t}, m_{t-1}\right)$ は $m_{t}=m_{t-1}$ のときに 1 となるクロネッカーのデルタで ある。本定義は，右辺第一項で行動素が遷移する場合を表 し，第二項では遷移せずに現在の行動素の再生を続けるこ とを表している。

また遷移のしやすさ $r(x)$ については，ある行動素の再生 が終わりそうになるほど次の行動素へと遷移しやすくなる ので, 状態 $x$ のフレーム位置 $f$ がその行動素 $m$ の終端に近 づくほど 1 に近くなるような分布にすれば良い。本研究で は，簡単のため $r(x)=r(m, f, v)$ を次のように定義する。

$$
r(x)= \begin{cases}1-\varepsilon & f_{m}<f+v \\ \varepsilon & \text { otherwise }\end{cases}
$$

ここで $\varepsilon$ は小さな正の数であり, $f_{m}$ は行動素 $m$ の終端フ レームである。ただし, 行動素 $m$ に遷移先が存在しない場 合は $r(x)=0$ とする。

$\langle\mathbf{4} \cdot \mathbf{2}\rangle$ 初期分布 状態 $x$ は遷移確率 $p\left(x_{t} \mid x_{t-1}\right)$ によっ て更新されるため, 初期時刻 $t=0$ での分布 $p\left(x_{t=0}\right)$ が必 要である。本研究での内部状態 $x=(m, f, v)$ について, フ レーム再生速度 $v$ は他からの影響を受けず，また，フレー ム位置 $f$ は行動素 $m$ の総フレーム数に影響を受けるので, 初期分布 $p\left(x_{t=0}\right)$ を次のようにして求める。

$$
\begin{aligned}
p\left(x_{t=0}\right) & =p\left(v_{t=0}, f_{t=0}, m_{t=0}\right) \cdots \cdots \cdots \cdots \\
& =p\left(v_{t=0}\right) p\left(f_{t=0} \mid m_{t=0}\right) p\left(m_{t=0}\right) \cdots
\end{aligned}
$$

なお, 初期行動素の分布 $p\left(m_{t=0}\right)$ については一様分布と する。

$\langle\mathbf{4} \cdot \mathbf{3}\rangle$ 状態遷移列とモデルの事後確率 内部状態 $x$ の 時系列 $x_{t-k: t}=\left\{x_{0}, x_{1}, \ldots, x_{t}\right\}$ が得られたときの行動モ デル $M$ の事後確率 $p\left(M \mid x_{t-k: t}\right)$ の推定について述べる。状 態 $x_{t}$ は現在の行動素 $m_{t}$ を含むように定義したため, 状態 系列 $x_{t-k: t}$ から行動素の遷移列 $m_{t-k: \tau}=\left\{m_{0} \rightarrow m_{1} \rightarrow\right.$ $\left.\cdots \rightarrow m_{\tau}\right\}$ を生成できる。行動モデルは行動素の遷移列で 表現されているので, 得られた遷移列 $m_{t-k: \tau}$ がモデル $M$ に含まれているかどうかによって事後確率 $p\left(M \mid x_{t-k: t}\right)$ の 計算ができる。

本研究では次のような方法で事後確率 $p\left(M \mid x_{t-k: t}\right)$ を求 める。まず, 行動素遷移列 $m_{t-k: \tau}$ が行動モデル $M$ に含ま れているかどうかを示す関数 $F\left(M, m_{t-k: \tau}\right)$ を用意する。

$$
F\left(M, m_{t-k: \tau}\right)=\left\{\begin{array}{ll}
1 & m_{t-k: \tau} \subset M \\
0 & \text { otherwise }
\end{array} \ldots\right.
$$

行動モデルの事後確率 $p\left(M \mid x_{t-k: t}\right)$ は, 関数 $F(\cdot)$ を用いて,

$$
p\left(M \mid x_{t-k: t}\right)=\frac{F\left(M, m_{t-k: \tau}\right)}{\sum_{i=1}^{N_{M}} F\left(M_{i}, m_{t-k: \tau}\right)} \ldots \ldots .
$$

とする。ただし， $N_{M}$ はデータベース内の行動モデルの数 である。

\section{5. 実 験}

本実験で用いた計算機を表 1 に示す。なお，本章におい て従来手法とは Matsumura ら (14)による手法のことであ り，また，行動の学習には Matsumura らが用いた手法を 利用した。Matsumura らの手法に関しては，付録に詳細 を示す。

$\langle\mathbf{5} \cdot \mathbf{1}\rangle$ 全方位動画像による評価実験 全方位視覚七 ンサ(15)を用いて人物が部屋の中を動く様子を撮影し, 得 られた動画像から人物の重心軌跡を抽出した。部屋の大き さは $7 \mathrm{~m} \times 7 \mathrm{~m}$ で，カメラを部屋の中央に設置した。全方 位画像の取得フレームレートは $30[\mathrm{fps}]$ であり, 得られた 全方位画像は $512 \times 440$ ピクセルで， 8 ビットのグレイス ケール画像である。部屋の様子の全方位画像と人物の追跡 によって得られた軌跡を図 5 に示す。各軌跡は 5 つの経路 を通った軌跡であり, 各経路 10 本, 合計 50 本ある。なお, 各軌跡は $10 \sim 15$ 秒ほどの長さである。

$\langle\mathbf{5} \cdot \mathbf{1} \cdot \mathbf{1}\rangle$ 検出性能 一 全方位画像 — 近似精度や例

Table 1. Experimental environment

\begin{tabular}{|c|c|}
\hline CPU & Dual 2 GHz PowerPC G5 \\
Memory & 1.5 GB DDR SD-RAM \\
OS & Mac OS X 10.4 \\
Compiler & $\mathrm{gcc} / \mathrm{g}++4.0 .1$ with optimization (-O2) \\
\hline
\end{tabular}


外の検出にはしきい值やサンプル数の影響を受けると考え られる。そこで，これらのパラメータを変えることで検出 率がどのように変わるかを調べた。ここで調べた項目は

FAR false accept ratio.

例外（未学習）行動を学習済みと判断する割合。

FRR false reject ratio.

学習済みの行動を例外として検出する割合。

の 2 種類である。実験方法は以下に示す通りである。

まず，全方位画像から得られた 50 本の重心軌跡を図 5 の ように各経路ごとに手作業でクラスタリングしておく。次 に，ある経路以外の軌跡を学習してデータベースを構築す る。そして，学習しなかった経路の軌跡を認識させ，例外 として検出されるかどうかを試みる。また，学習した経路 の軌跡についても認識処理を行い，学習済みと判断される かどうかも試みる。

図 6 にしきい值を変更したときの検出率を，また，図 7 にサンプル数を変更したときの検出率を示す。両図とも左 側がFAR，右側がFRRであり，実線が提案手法による結 果で，点線が従来手法による結果である。図 6 より，しき い值が大きいときはほとんどの行動を例外として検出する ために FRR が高くなり，FAR が低くなっている様子が分

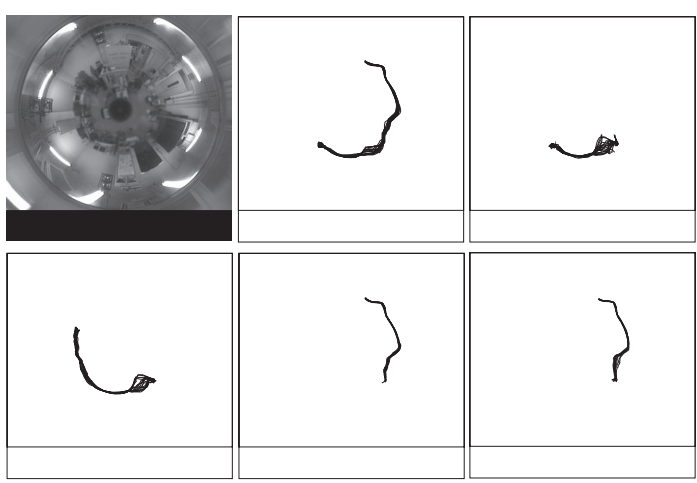

Fig. 5. Input image and trajectories

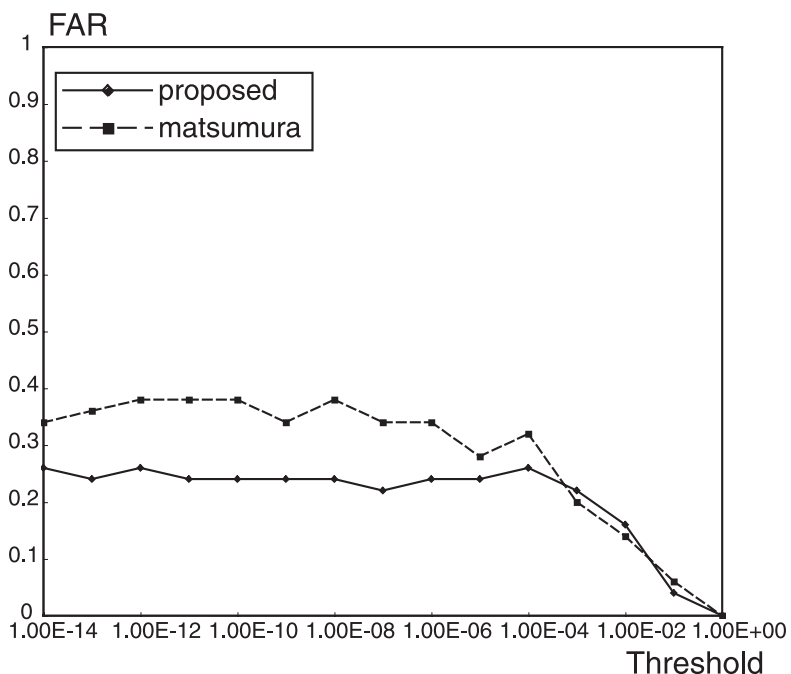

かる。また，しきい值を十分小さくするとそれ以上変化は ない様子も見て取れる。さらに，提案手法の方が従来手法 より良い結果を示している。これは，行動素の状態分布を 提案手法がより正確に表現できていることを示している。 なお，図中ではグラフは横ばいになってはいるが，しきい 值を非常に小さくすると，それは例外行動検出を行わない という意味になるので，あまり小さくしすぎないほうが良 いと思われる。次に図 7 では，サンプル数が少ないと分布 の近似精度が悪くなるために，FRR が高く，FAR が低く なっている様子が分かる。ただし，近似精度の向上のため にサンプル数を増やすと, 認識アルゴリズムの計算コスト がサンプル数に比例するため, 実行速度とのトレードオフ になる。

さて，両図から FAR，FRR ともにある程度以上は改善 されていない様子が分かる。まず，FAR に関しては次の理 由が考えられる。学習した行動について, 図 5 をみると, 図の中央下の行動は中央上の行動に含まれていることが分 かる。また，本研究での例外検出手法は内部状態の観測特 徵量に対する尤度のみを利用している。このため, 図 5 の 中央下の行動を学習していなくても中央上の行動を学習し ている場合は, 中央下の軌跡を認識処理に入力したときに 尤度が一向に下がらないため, データベースに含まれると 判断される。これは本実験では false accept として扱われ てしまうため, その結果 FAR が上昇する。これを回避する ためには，学習済みの行動の一部分のみ行う行動を例外と して扱う必要がある。そのためには行動の開始状態と終了 状態を行動素の遷移に含めれば良いが，このような行動を 本当に例外として扱うかについては今後の検討課題とする。

一方，FRR については，サンプル数が足りず近似精度が 悪いことが理由にあげられるが，他に，データベースの学 習精度の問題があげられる。たとえば，本研究で用いた学 習手法に図 5 の全ての軌跡を学習させると，9つの行動乇 デルが生成されたが, 図の経路は 5 つなので先長で複雑な データベースが生成されている。データベースが複雑にな

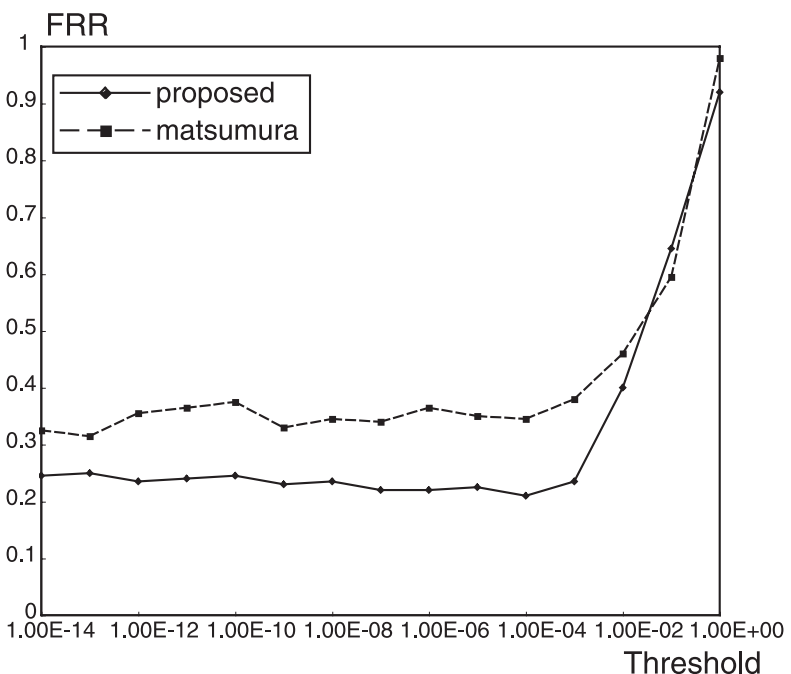

Fig. 6. Suspicious action detection rates varying the threshold value 


\section{FAR}

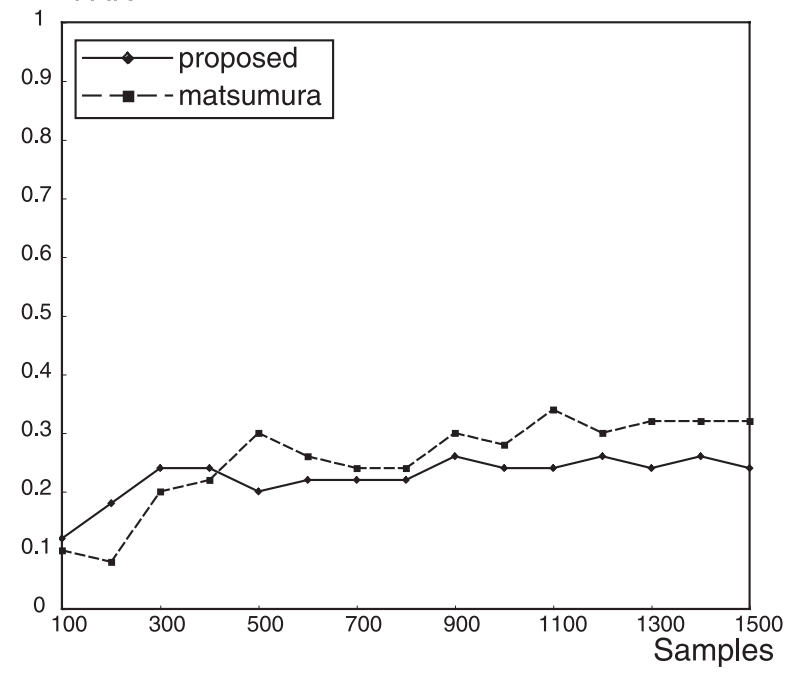

FRR

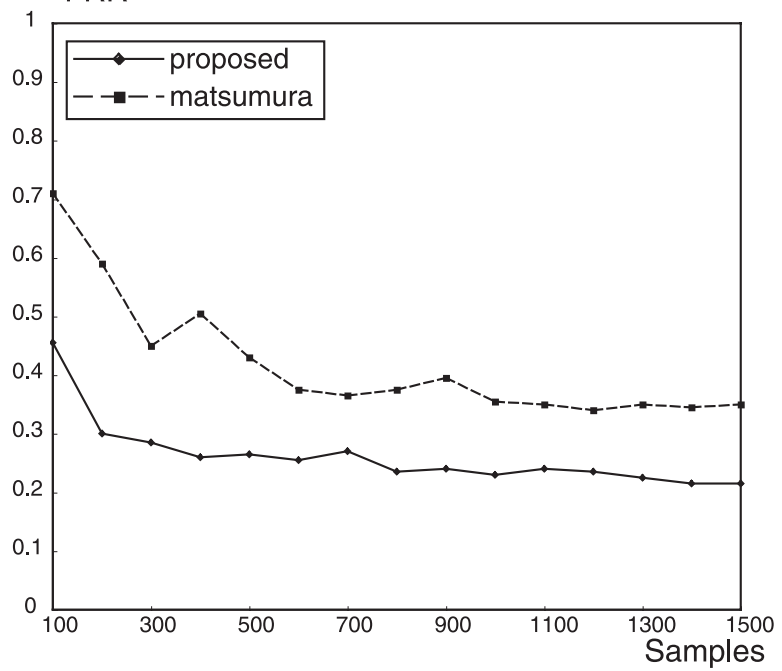

Fig. 7. Suspicious action detection rate waring the number of samples

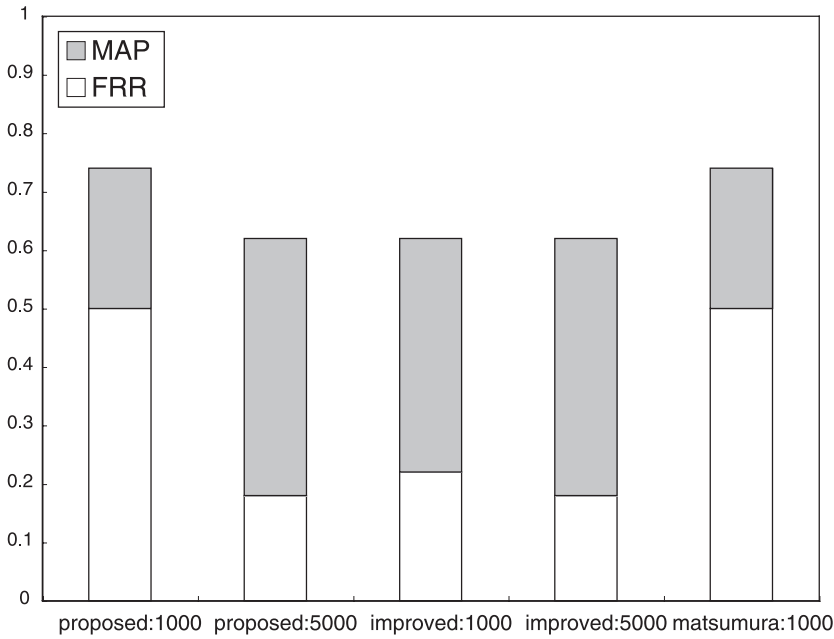

Fig. 8. Comparison of recognition rates

れば, 分布の近似に多数のサンプルが必要になるため, 学 習精度が原因で誤検出したと考えられる。精度の良い学習 方法については今後の課題とする。

次に, 認識処理によって得られた行動モデルの事後確率 から MAP 推定を行い, 行動認識を行った。その結果を図 8 に示す。実験にはテスト用の軌跡以外を学習して, テスト 用軌跡を認識するジャックナイフ法を用いた。ここで実験を 行った手法は, 図の左から, 提案手法でサンプル数を 1000 個にしたもの，同じく5000 個で行ったもの，続いて，提 案手法を $\langle 3 \cdot 5\rangle$ 節で述べた方法によって改良したもので，サ ンプル数を 1000 個にしたものと 5000 個にしたもの，最後 に従来手法でサンプル数を 1000 個にしたものである。棒 グラフの白い部分が FRR で，灰色の部分が MAP 推定で 認識に成功した割合である。認識に成功したかどうかの判 定は, テスト軌跡が自分と同じ経路に属する軌跡の行動モ デルと同一と判断されるかどうかで行った。眓 8 より, 従 来手法や提案手法では FRR が高いことが分かる。この原

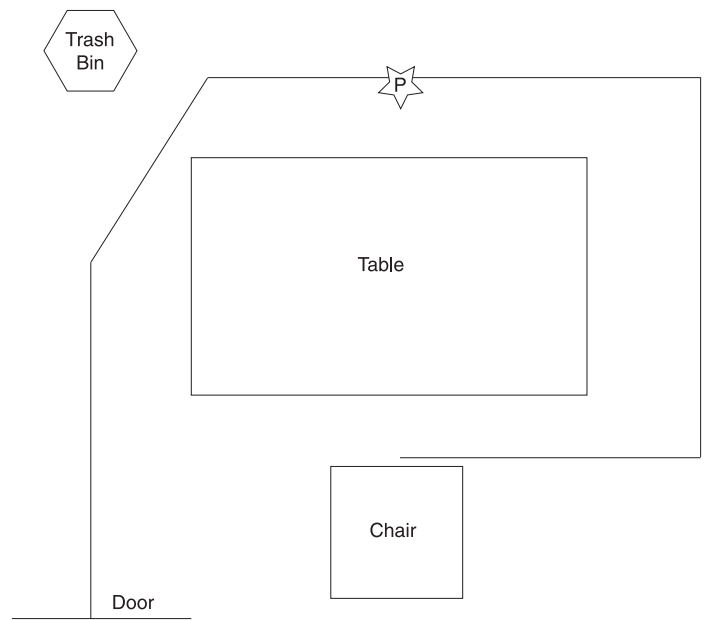

Fig. 9. Layout of experimental room

因は，〈3・5〉節で述べた通り，直前の状態のみを利用して状 態遷移を行っているために起こるものであると考えられる。 FRR は図に示した通り, サンプル数を増やすことで低く抑 えることができてはいるが，実効速度を調べてみると，サ ンプル数が 1000 個のときにはおよそ $32[\mathrm{fps}]$ であったのに 対し，5000 個のときは約 $6[\mathrm{fps}]$ に下がっており，認識処理 のリアルタイム性で大きな問題が生じる。そこで, 認識処理 に〈3・5〉節で述べた改良を施したところ, 図 8 の通り, サン プル数が 1000 個でも 5000 個のときの性能に近くなった。

$\langle\mathbf{5} \cdot 2\rangle$ 頭部位置による評価実験 次に，モーション キャプチャを利用して, 室内での人物の移動軌跡を取得し, 同様な評価実験を行った。行動を表す特徵量は人物頭部の 三次元位置である。行動を取得した室内の様子を図 9 に示 す。人物の移動範囲は約 $4 \mathrm{~m} \times 4 \mathrm{~m}$ であり, 取得した行動は 次の 3 種類である。また，モーションキャプチャのデータ の取得フレームレートは $30[\mathrm{fps}]$ である。

秘書行動 約 20 秒の行動。 
図 9 にて, ドアより入室し, 地点 $\mathrm{P}$ でテーブルにお茶 を出し，ドアまで戻って退出する。

事務作業 約 50 秒の行動。

図 9 にて，ドアからテーブルの周りを時計回りに一周す るように歩いて椅子に座り，テーブルにて新聞を読む。 その後，入室時のルートを逆に迻り退室する。

テーブル掃除 約 70 秒の行動。

図 9 にて, ドアからテーブルの周りを時計回りに一周す るように歩いて椅子に座る。テーブルの上を片付けた後, 反時計回りに地点 $\mathrm{P}$ を経由してゴミ箱まで歩き，ゴミを 捨てる。そして，時計回りで椅子まで戻り，着席した後 テーブルの上を拭く。作業が終わったら，テーブルの周 りを反時計回りで歩いて，そのままドアより退出する。

被験者の数は 8 人であり, それぞれに 3 種類の行動を $4 \sim 6$ 回行ってもらい, 合計で 108 本の軌跡を取得した。

$\langle\mathbf{5} \cdot \mathbf{2} \cdot \mathbf{1}\rangle \quad$ 検出性能 —モーションキャプチャ—— 前 節の実験と同様に，しきい值やサンプルの数の影響を調べ た。実験データとして，被験者一人の行動軌跡を用いた結 果を図 10 に，被験者全員の軌跡を用いた結果を図 11 に示 す。図 $10(\mathrm{a}), 11(\mathrm{a})$ がしきい值を変更したときの FRR の変化の様子で, 図 10 (b), 11 (b) はサンプル数を変更し たときの FRR の変化の様子である。なお，FAR は実験を 行ったパラメータの範囲で全て 0 となった。図 10 と図 11 より，提案手法は被験者一人の行動を用いたときに従来手 法よりも検出率が高くなっているが，被験者全員の行動軌 跡を用いたときには，従来手法よりも低くなっている様子 が分かる。このことから，提案手法はデータベースの大き さの影響を受けやすいと考えられる。この原因は $\langle 3 \cdot 5\rangle$ 節で 述べた通り，提案手法は直前の状態のみを利用して状態遷 移を行っているためと考えられる。そこで，〈3・5〉節の改良 を施したところ，図 10，11の通り，改良手法の検出率が 最良となった。

また，図 $10(\mathrm{a}), 11(\mathrm{a})$ の通り，しきい值を小さくする ことによって FRR を低くすることができている。ただし， しきい值を小さくすることは例外検出を行わないという意 味になるので，あまり小さくしすぎると FAR が上昇する 可能性がある。一方, サンプル数については, 図 $10(\mathrm{~b})$, 11 (b) の通り，サンプル数を増やすことで FRR を低くす ることができる。これは分布の近似精度が良くなるためで あるが，認識アルゴリズムの計算コストはサンプル数に比 例するため，実行速度とのトレードオフになる。

さらに，図 11 を図 10 と比べてみると, 検出性能が非常 に低くなっている様子が分かる。これは，データベースの規 模に対してサンプルの数が少なく，近似精度が悪いことが 原因としてあげられるが，他に，データベースの学習精度 の問題があげられる。例えば，本実験で手作業でクラス夕 リングした結果, 同じクラスタに属する行動の軌跡を学習 させると，異なる行動素の遷移列が生成されることがあっ た。これは学習の際に, 人物間の差異や各軌跡の観測ノイ ズを吸収しきれず，圥長で複雑なデータベースが生成され

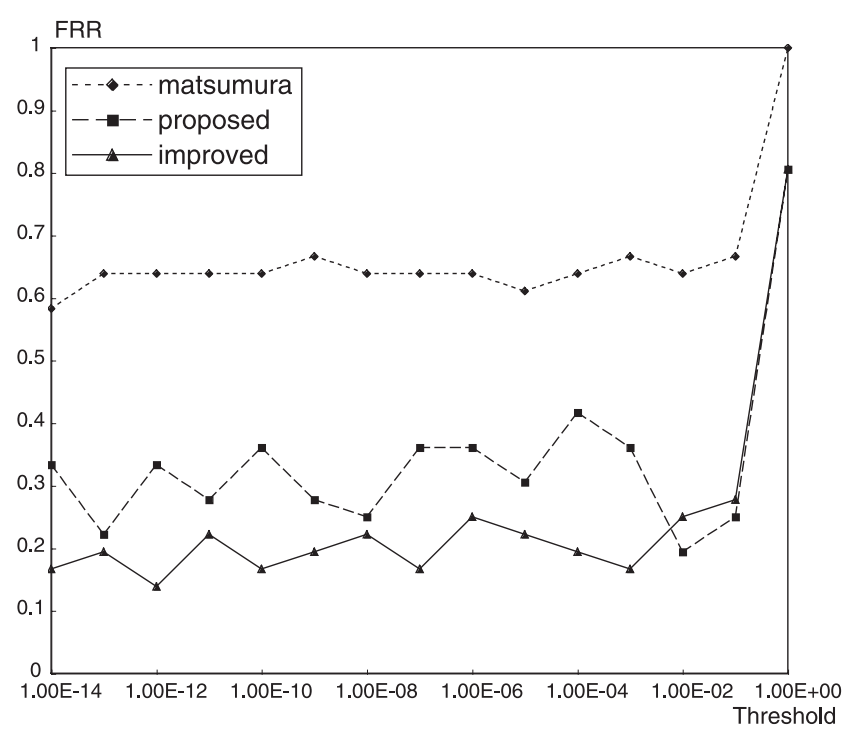

(a) Suspicious action detection rate varying the threshold value

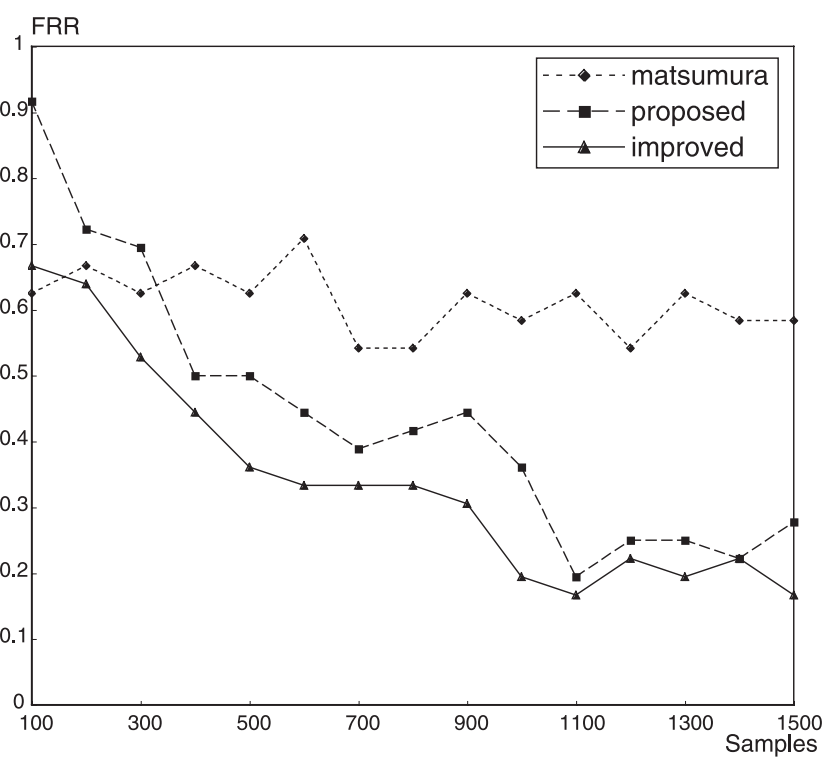

(b) Suspicious action detection rate varying the number of samples

Fig. 10. Detection rates learned by one person's trajectories in the action database

ていると考えられる。データベースが複雑になれば，分布 の近似に多数のサンプルが必要になるため，学習精度が原 因で誤検出したと考えられる。精度の良い学習方法につい ては今後の課題とする。

〈5·2·2 FAR について 〈5・2・1〉節での実験では FAR は 0 となったが, 本研究での例外検出手法は内部状 態の観測特徵量に対する尤度 $p\left(z_{t} \mid x_{t}\right)$ のみを利用している ため, 次のような状況が存在する。ある行動 $M_{1}$ が別の行 動 $M_{2}$ の一部分であるとき, データベースに行動 $M_{2}$ を学 習済みで，かつ，行動 $M_{1}$ は未学習の場合を考える。この 状態で行動 $M_{1}$ に属する軌跡を認識処理に入力すると，行 動 $M_{1}$ は行動 $M_{2}$ の一部分であるため, 認識処理中に尤度 が下がることは無く，したがって例外として検出されない。 すなわち, $\langle 5 \cdot 2 \cdot 1\rangle$ 節での実験では false accept として扱 


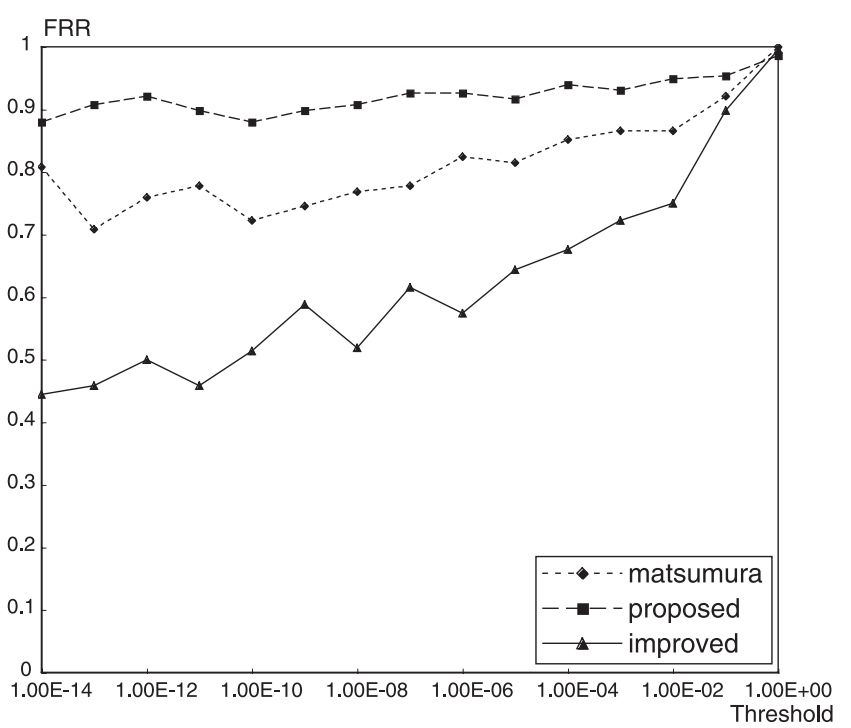

(a) Suspicious action detection rate varying the threshold value

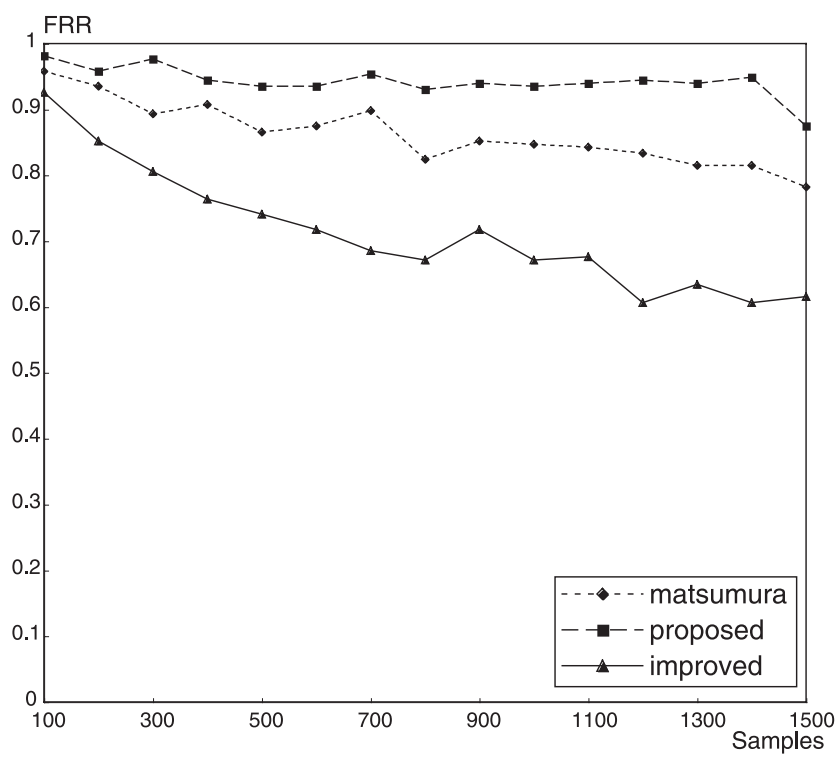

(b) Suspicious action detection rate varying the number of samples

Fig. 11. Detection rates learned by all trajectories in the action database

われ，その結果 FAR が上昇する。これを回避するために は，学習済みの行動の一部分のみを行う行動を例外として 扱えば良いが，このような行動を本当に例外として検出す るかどうかについては議論が必要である。

〈5・2・3〉 行動モデル認識率 次に, 認識処理によって 得られた行動モデルの事後確率 $p\left(M_{t} \mid z_{t-k: t}\right)$ から MAP 推 定を行い，行動認識を行った。その結果を図 12 に示す。こ こで, 図 12 (a) は被験者一人の行動軌跡のみを用いて行っ た結果であり, 図 12 (b) は被験者全員の軌跡を用いて実験 を行った結果である。実験には, テスト用の軌跡以外を学 習してテスト用軌跡を認識する，ジャックナイフ法を用い た。ここで実験を行った手法は, 提案手法でサンプルの数 を 1000 個にしたもの，同じく 5000 個で行ったもの，続い て，提案手法を〈3・5〉節で述べた方法によって改良したも

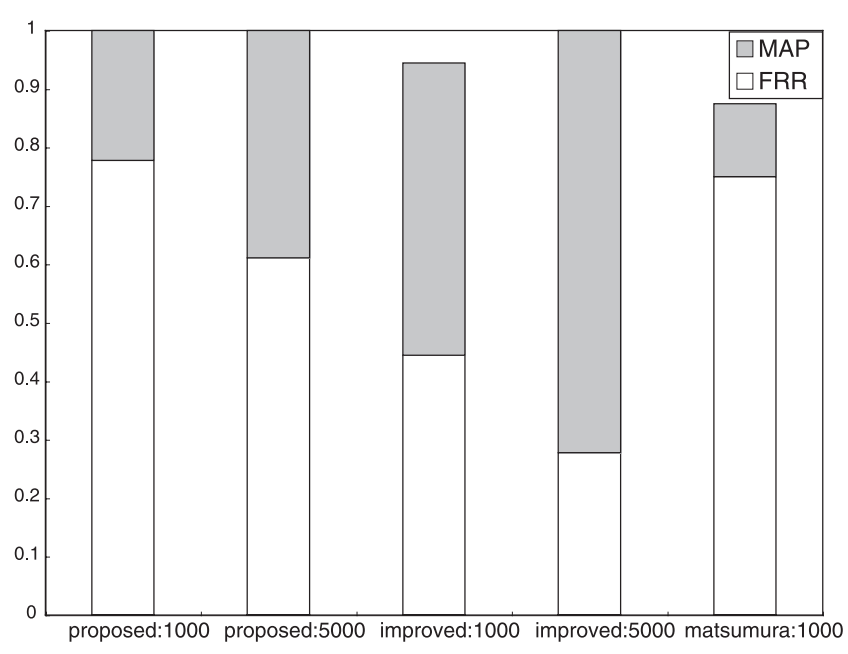

(a) Classifiers are learned by one person's trajectories in the action database

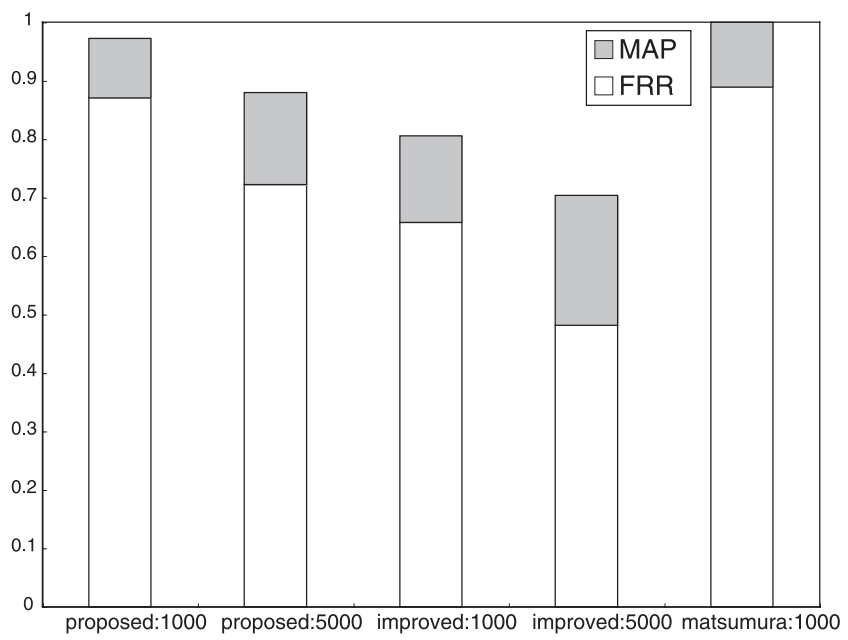

(b) Classifiers are learned by all trajectories in the action database

Fig. 12. Comparison of recognition rates

ので, サンプル数を 1000 個にしたものと 5000 個にしたも の, 最後に従来手法でサンプル数を 1000 個にしたもので ある。図 12 の棒グラフの白い部分が FRR で，灰色の部 分が MAP 推定で認識に成功した割合である。認識に成功 したかどうかの判定は，テスト軌跡が自分と同じ行動に属 する軌跡の行動モデルと同一と判断されるかどうかで行っ た。図 12 より，全員の軌跡を用いた場合では認識率が低 い様子が分かる。これは, データベースの学習精度の低さ が大きな原因と考えられる。また，従来手法や改良無しの 提案手法では FRR が高く, 改良の効果が大きい様子が分 かる。しかし，認識率自体は低いため，まだ改良が必要で ある。

〈5·2・4〉 例外行動の認識 ここでは, はじめに用意 した 108 本の軌跡を学習したデータベースに対して，それ 以外の軌跡を例外として検出できるかどうか試みた。例外 行動として用意した軌跡は次の 3 種類である。

case 1 図 9 で, ドアから入室し, 地点 $\mathrm{P}$ まで歩き, テーブルの上の物体を取る。その後, 走って退室する。 case 2 図 9 で, ドアより入室後, 中腰で歩いて地点 $\mathrm{P}$ 
まで往復する。

case 3 図 9 の右上隅から進入し, 左上隅まで移動する。 以下に実験の結果をまとめる。まず, case 3 は行動の開 始フレームから例外として検出することに成功した。これ は, 類似する行動が全く存在しないためである。残りの 2 種類の例外行動の場合は, 途中のフレームまで通常行動と して認識された後, 例外として検出された。case 1 では, 地点 $\mathrm{P}$ まで歩いた後, 走りはじめたときに例外として検 出され, case 2 では, 入室後, 中腰になってから検出され た。いずれの場合も, 例外発生時に検出することに成功し たと言える。ただし，どちらも例外発生から 20 フレームほ ど経過してから例外として検出された。これは，全てのサ ンプルの尤度がしきい值を下回るまで時間が必要なためで ある。したがって, サンプルの数としきい值は注意して選 ぶ必要がある。

\section{6. おわりに}

本研究では, 予め頻繁に観測される行動を行動モデルと して学習し行動認識を行うことで, 未知の行動を観測した ときに例外として検出する手法を提案した。行動モデルは 行動素の遷移列によって表現し, 認識手法は時系列べイズ 推定によって定式化し, 逐次モンテカルロ法を用いて近似 的に計算した。 2 種類の異なる特徵量を用いた実験により， 本手法が行動認識と例外検出のフレームワークを提供する ことが示された。また, 行動素の多峰性分布を混合分布で 表現することにより, 従来手法と比べて, 例外行動の検出 率が改善されることも明らかになった。提案手法に対して 実験を行った結果, 未学習の行動を例外発生として検出す ることに成功したが, 学習済みの行動も䛊って例外として 検出することがあった。この原因としては, 行動モデルの 学習精度が低いことが考えられる。なお，本研究で行った 評価実験では，行動の特徵量として人物位置のみを用いた が, この場合，腕や手などの細かい動きを扱うことができ ないため, 認識できる行動の範囲が小さい。今後は, 腕や 手などの細かい動きの特徴量も追加してより複雑な行動や 例外の検出を試みる必要がある。また，精度の良いデータ ベースの構築方法の検討や人物の行動を表せるものとして 最適な特徴量の検討や, 行動の種類や学習する数を増やし た場合の検出率の評価などが挙げられる。

(平成 21 年 7 月 10 日受付, 平成 21 年 11 月 17 日再受付)

\section{文献}

（1）（財）マイクロマシンセンター：「次世代マイクロマシン技術応用シ ステムの創出に関する調査研究報告書」, 技術報告, (財) マイクロ マシンセンター (2001)

(2) P. Viola and M. J. Black: "Rapid object detection using a boosted cascade of simple features", Computer Vision and Pattern Recognition, Vol.I, pp.511-518 (2001).

(3) P. Pérez, C. Hue, J. Vermaak, and M. Gangnet: "Colorbased probabilistic tracking", European Conf. Computer Vision (ECCV 2002), pp.661-675 (2002)

(4) K. Sumi, M. Seki, and H. Habe: "Object detection: model of foreground and background", IPSJ SIG Notes. Vol.CVIM 2005 (88), pp.79-98, (2005-9) (in Japanese)

塈見和彦・関真規人・波部 斉:「物体検出 - 背景と検出対象の モデリング -」, In 情処研報 CVIM, Vol.CVIM 2005, pp.79-98 (2005-9)

(5) T. Nanri and N. Otsu: "Anomaly Detection in Motion Images Containing Multiple Persons", Trans. of IPSJ, Vol.SIG-15 (CVIM-12), pp.43-50 (2005-10) (in Japanese) 南里卓也 - 大津展之 : 「複数人物動画像からの異常動作検出」, 情処 学論 CVIM, Vol.SIG-15 (CVIM-12), pp.43-50 (2005-10)

(6) O. Boiman and M. Irani: "Detecting irregularities in images and in video", Int'l. J. Computer Vision, Vol.74, No.1, pp.17$31(2007)$

（7） 中川聖一：「確率モデルによる音声認識」，コロナ社 (1988)

(8) N. Oliver, B. Rosario, and A. Pentland: "A bayesian computer vision system for modeling human interactions", IEEE Trans. PAMI, Vol.22, No.8, pp.831-843 (2000-8)

（9）青木茂樹·岩井嘉男·大西正樹・小島篤博 - 福永邦雄：「人物の位 置・姿勢に注目した行動パターンの学習・認識と非日常状態検出へ の応用」, 信学論 D-II, Vol.87, No.5, pp.1083-1093 (2004-5)

10) M. Isard and A. Blake: "A mixed-state CONDENSATION tracker with automatic model-switching", Int'l. Conf. Computer Vision, pp.107-112 (1998)

(11) M.J. Black and A. D. Jepson: "A probabilistic framework for matching temporal trajectories: CONDENSATION-based recognition of gestures and expressions", European Conf. Computer Vision, pp.909-924 (1998)

(12) A. Matsumura, Y. Iwai, and M. Yachida: "Stochastic Action Recognition From Omnidirectional Images", Asian Conf. Computer Vision, pp.120-125 (2004)

(13) J. Vermaak, A. Doucet, and P. Pérez: "Maintaining multimodality through mixture tracking", Int'l Conf. Computer Vision, Vol.2, pp.1110-1116 (2003)

(14) A. Matsumura, Y. Iwai, and M. Yachida: "Tracking people and action recognition from omnidirectional images", System and Human Science, ch.37, pp.501-514, Elsevier (2005)

（15）山澤一誠：「全方位視覚センサ HyperOmni Vision に関する研究一 移動ロボットのナビゲーションのために一」博士学位論文, 大阪大 学 (1997)

\section{付 録}

\section{1. 行動モデルの学習}

本研究では, 行動モデルの学習手法として, Matsumura ら (14) が用いた手法を利用している。ここではその手法に ついて簡単に説明する。

$\langle\mathbf{1} \cdot \mathbf{1}\rangle$ 静止点の除去 学習用の入力軌跡 $z=I(t)$ が 入力されたときに，まず人物が静止している点を探索し， 入力軌跡中の静止している区間を除去する。静止点は, 現 在の行動を示す観測特徴量 $I(t)$ を中心としてその前後のフ レーム（フレーム幅を $2 F$ とする）での特徴量より分散 $V_{t}$ を算出する。

$$
V_{t}=\frac{1}{2 F+1} \sum_{f=t-F}^{t+F}(I(f)-I(t))^{2} \cdots \cdots \cdots
$$

分散 $V_{t}$ がしきい値 $T_{S}$ 以下となるフレームを人物が静止し ているとみなす。以下では, 行動モデルの学習や認識処理を 行う際に, 前処理として静止点の探索を行い, もとの入力軌 跡から静止点を除去したものをあらたな入力軌跡 $z=I(t)$ として用いる。

$\langle\mathbf{1} \cdot \mathbf{2}\rangle$ 行動素の自動生成 行動モデル学習のための 行動素の抽出は, 以下に示すアルゴリズムにより自動的に 行われる。入力軌跡 $I(t)$ のフレーム $s$ からフレーム $e$ 間の 軌跡を $I_{s: e}$, データベースに学習済みの行動素を $m_{i}$, 軌跡 
$I_{s: e}$ と行動素 $m_{i}$ が示す軌跡との類似度を $D\left(I_{s: e}, m_{i}\right)$ とし,

$$
D\left(I_{s: e}, m_{i}\right)=\frac{1}{f_{m_{i}}} \sum_{t=1}^{f_{m_{i}}} \exp \left(-\frac{d(t)}{2}\right) \ldots \ldots \ldots
$$

で求める。ここで, $f_{m_{i}}$ は行動素 $m_{i}$ の総フレーム数であ り, $d(\cdot)$ は次式によって計算する。

$$
d(t)=\left(I_{s: e}(\alpha t)-m_{i}(t)\right)^{T} \Sigma^{-1}\left(I_{s: e}(\alpha t)-m_{i}(t)\right)
$$

とする。ここで, $I_{s: e}(t)=I(t+s), \alpha=(e-s) / f_{m_{i}}$ で あり， $\Sigma$ は共分散行列である。

行動素は次のようにして生成する。なお，初期のデー夕 ベース内の行動素を $m=\left\{m_{k} \mid k=1, \ldots, N_{m}\right\}$ とする。

Step 1 入力された軌跡 $I(t)$ の中にデータベース内の行 動素が含まれていないか探索する。入力軌跡中のある区 間 $I_{s: e}$ と, 行動素 $m_{i}$ との類似度 $D\left(I_{s: e}, m_{i}\right)$ を計り, 最 大の類似度 $D_{\max }$ となる $I_{s: e}$ と $m_{i}$ を決める。

Step 2 最大の類似度 $D_{\text {max }}$ がしきい值 $T_{D}$ 以上であれ ば，そのときの $I_{s: e}$ は行動素 $m_{i}$ であるとする。入力軌 跡 $I(t)$ から $I_{s: e}$ を取り除き, 残った前後の軌跡をそれぞ れ新たな入力軌跡 $I(t)$ として, 再び行動素を探索するた めStep 1 を繰り返す。ただし， $I(t)$ の長さ（総フレー 厶数）がしきい值 $T_{L}$ 以下の場合は探索を行わず，無効 な軌跡として棄却する。

Step 3 最大の類似度 $D_{\max }$ がしきい值 $T_{D}$ 未満であれ ば, 入力軌跡 $I(t)$ 中に含まれる行動素はデータベース内 に存在しない。そこで, $I(t)$ 全体を新たな行動素として データベースに登録し，これを $m_{\text {new } 1}$ とする。

Step 4 データベース内の行動素の中に新しく生成さ れた行動素 $m_{\text {new } 1}$ が含まれていないか探索する。デー タベース中の各行動素の軌跡を入力軌跡 $I(t)$ とし, そ の中のある区間の軌跡 $I_{s: e}$ と新規行動素 $m_{\text {new } 1}$ との 類似度 $D\left(I_{s: e}, m_{\text {new } 1}\right)$ を求める。ここで, ある行動素 $m_{j}$ を入力軌跡 $I(t)$ としたときの類似度 $D\left(I_{s: e}, m_{\text {new 1 }}\right)$ の最大值 $D_{\max }$ がしきい值 $T_{D}$ 以上となれば, 行動素 $m_{j}$ に $m_{\text {new } 1}$ が含まれるとする。この場合, 行動素 $m_{j}$ の軌跡から $D_{\max }$ となる $I_{s: e}$ を除いた前後の軌跡を, それぞれ新たに $m_{\text {new } 2}, m_{\text {new } 3}$ としてデータベースに 登録し, 行動素 $m_{j}$ をデータベース内から削除する。 従ってこの時点でのデータベースは, $m=\left\{m_{k} \mid k=\right.$ $\left.1, \ldots, m_{j-1}, m_{j+1}, \ldots, N_{m}, m_{\text {new } 1}, m_{\text {new } 2}, m_{\text {new } 3}\right\}$ と なる。ただし, 新規行動素 $m_{\text {new } 2,}, m_{\text {new } 3}$ の長さがしき い值 $T_{L}$ 以下であれば，その行動素は棄却する。
Step 5 新規行動素 $m_{\text {new } 2,}, m_{\text {new } 3}$ がデータベース中 の行動素に含まれていないか, Step 4 と同様にして探索 を行う。

以上の操作を新たな行動素が生成されなくなるまで繰り返 す。このアルゴリズムにより, 入力軌跡が行動素の遷移列 によって表され，その遷移列が一つの行動モデルとなる。 行動素の遷移列が同じ行動モデルは同一の行動モデルとし て学習する。また, 遷移先を決定する分布 $p\left(m_{i} \mid m_{j}\right)$ も同 時に学習しておく。

岩 井 儀 雄 (非会員) 1992 年阪大·基礎工・情報卒業。1994

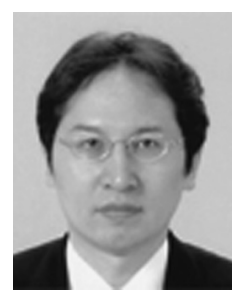
年同大大学院基礎工学研究科修士課程修了。1997 年同大大学院基礎工学研究科博士課程修了。同年 同大学院基礎工学研究科助手, 2003 年同大学院 助教授。2004 2005 年英国ケンブリッジ大学に て客員研究員。コンピュータビジョン, パターン 認識に関する研究に従事。博士 (工学)。IEEE, 電子情報通信学会, 情報処理学会, 日本ロボット

学会各会員。

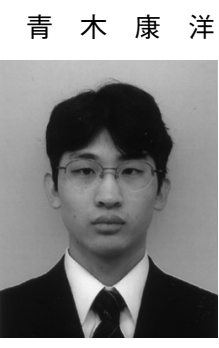

（非会員） 2005 年阪大・基礎工・システム科学 科卒業。2007 年同大大学院基礎工学研究科博士 前期課程修了。同年富士通入社。

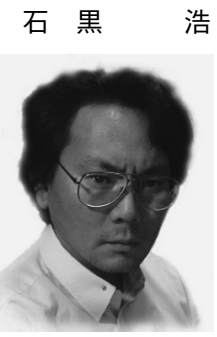

浩（非会員） 1991 年大阪大学大学院基礎工学研究 科物理系専攻修了。工学博士。同年山梨大学工学 部情報工学科助手。1992 年大阪大学基礎工学部 システム工学科助手。1994 年京都大学大学院工 学研究科情報工学専攻助教授, 1998 年同大学大 学院情報学研究科社会情報学専攻助教授。この間, 1998 年より 1 年間, カリフォルニア大学サンディ エゴ校客員研究員。2000 年和歌山大学システム 工学部情報通信システム学科助教授, 2001 年同大学教授。 2002 年大 阪大学大学院工学研究科知能 - 機能創成工学専攻教授, 2009 年より同 大学大学院基礎工学研究科システム創成専攻教授。1999 年 ATR 知 能映像研究所客員研究員, 2002 年よりATR 知能ロボティクス研究 所客員室長。知能ロボット, アンドロイドロボット, 知覚情報基盤の 研究に興味を持つ。 